\title{
Conceptual framework for outcomes research studies of hepatitis C: an analytical review
}

This article was published in the following Dove Press journal:

Infection and Drug Resistance

27 May 2016

Number of times this article has been viewed

\author{
Urbano Sbarigia' \\ Tom R Denee' \\ Norris G Turner ${ }^{2}$ \\ George J Wan ${ }^{3}$ \\ Alan Morrison ${ }^{4}$ \\ Anna S Kaufman ${ }^{4}$ \\ Gary Rice ${ }^{5}$ \\ Geoffrey M Dusheiko 6,7 \\ 'Janssen Pharmaceutica, Beerse, \\ Belgium; 'Johnson \& Johnson Health \\ Care Systems, Inc., Titusville, NJ, \\ ${ }^{3}$ Mallinckrodt Pharmaceuticals, St. \\ Louis, MO, USA; ${ }^{4}$ ScribCo, Effort, PA, \\ USA, ${ }^{5}$ Diplomat Specialty Pharmacy, \\ Flint, MI, USA, ${ }^{6}$ The University College \\ London Medical Institute for Liver \\ and Digestive Health, London, UK; \\ ${ }^{7}$ Kings College Hospital, London, UK
}

Correspondence: Urbano Sbarigia Janssen Pharmaceutica, Turnhoutseweg 30, B-2340 Beerse, Belgium Tel +32474943357

Email usbarigi@its.jnj.com

\begin{abstract}
Hepatitis $\mathrm{C}$ virus infection is one of the main causes of chronic liver disease worldwide. Until recently, the standard antiviral regimen for hepatitis $\mathrm{C}$ was a combination of an interferon derivative and ribavirin, but a plethora of new antiviral drugs is becoming available. While these new drugs have shown great efficacy in clinical trials, observational studies are needed to determine their effectiveness in clinical practice. Previous observational studies have shown that multiple factors, besides the drug regimen, affect patient outcomes in clinical practice. Here, we provide an analytical review of published outcomes studies of the management of hepatitis $\mathrm{C}$ virus infection. A conceptual framework defines the relationships between four categories of variables: health care system structure, patient characteristics, process-of-care, and patient outcomes. This framework can provide a starting point for outcomes studies addressing the use and effectiveness of new antiviral drug treatments.
\end{abstract}

Keywords: chronic hepatitis $\mathrm{C}$, humans, treatment outcome, combination drug therapy, antiviral agents

\section{Introduction}

Hepatitis $\mathrm{C}$ virus (HCV) infection is one of the main causes of chronic liver disease worldwide. ${ }^{1}$ According to recent estimates, more than 185 million people around the world have been infected with $\mathrm{HCV}^{2,3}$ The prevalence of hepatitis $\mathrm{C}$ infection varies substantially, with the highest estimated prevalence in Central and East Asia (3.8\% and 3.7\%, respectively) and in the North Africa/Middle East regions (3.6\%) of the world. ${ }^{4}$ While an estimated $15 \%-30 \%$ of all HCV infections clear spontaneously, most evolve to chronic hepatitis, which can lead to cirrhosis and hepatocellular carcinoma. ${ }^{5,6}$ Progression of liver disease may be influenced by various factors, including the duration of infection, alcohol abuse, and coinfection with hepatitis B virus (HBV) and human immunodeficiency virus (HIV). ${ }^{7}$

Eleven HCV genotypes (designated 1-11) with several distinct subtypes (designated $\mathrm{a}, \mathrm{b}, \mathrm{c}$, etc) have been identified. Genotypes 1-3 have a worldwide distribution with types $1 \mathrm{a}$ and $1 \mathrm{~b}$ accounting for roughly $60 \%$ of global infections. ${ }^{8}$ Genotype $1 \mathrm{a}$ is most often found in Northern Europe and North America, while genotype 1b is primarily found in Southern and Eastern Europe as well as Japan. Type 3 is endemic in Southeast Asia and is erratically distributed in different countries. Genotype 4 is largely found in the Middle East, Egypt, and Central Africa, while type 5 is almost entirely found in South Africa. Genotypes 6-11 are distributed throughout Asia. ${ }^{8}$

Treatment with antiviral drugs can reduce the hepatitis $C$ viral load in serum to undetectable levels. A sustained viral response (SVR) is defined as undetectable HCV 
RNA at 12 (SVR12) or 24 weeks following completion of drug therapy. ${ }^{9}$ Patients who achieve SVR have substantially reduced risk of progression to cirrhosis, development of hepatocellular carcinoma, and both liver-related and allcause mortality. ${ }^{10}$

Until 2011, the combination of pegylated interferon $\alpha-2$ (administered weekly by subcutaneous injection) and twice-daily oral ribavirin for either 24 (genotypes 2 and 3 ) or 48 weeks (genotype 1 and others) was the approved treatment for chronic hepatitis $\mathrm{C}$ in both the European Union and the United States. ${ }^{11}$ With this regimen, HCV genotype 1-infected patients had SVR rates of approximately $40 \%-50 \% .{ }^{11}$ In 2011, the European Medicines Agency (EMA) and the US Food and Drug Administration (FDA) approved two new oral antivirals for HCV genotype 1 infections: the direct-acting antivirals (DAAs), telaprevir and boceprevir. In clinical trials, addition of these DAAs to pegylated interferon $\alpha-2$ and ribavirin improved SVR rates in treatment-naïve, HCV genotype 1-infected patients. ${ }^{12-15}$

Three new, once-daily oral DAAs were approved by the EMA in 2014: simeprevir, sofosbuvir (both approved by the FDA in 2013), and daclatasvir (approved by the EMA in 2014 and by the FDA in 2015). ${ }^{11,16-19}$ When used as a component of a combination regimen, typically with pegylated interferon $\alpha-2$ and ribavirin, these new DAAs have led to improvements in SVR rates. ${ }^{11}$ Such triple regimens have the drawback, however, of increased regimen complexity and the potential for additional adverse effects.

Hepatitis $\mathrm{C}$ treatment is rapidly evolving away from interferon- and ribavirin-based therapy. ${ }^{20}$ Combinations of DAAs, including simeprevir plus sofosbuvir as well as daclatasvir plus sofosbuvir, have shown great efficacy. New, once-daily fixed-dose combinations of ledipasvir/sofosbuvir and ombitasvir/paritaprevir/ritonavir have been formulated, the latter copackaged with twice-daily dasabuvir tablets. Both treatments were approved by the EMA and FDA in late 2014 and are indicated as 12-24-week courses for HCV genotype 1 infections. ${ }^{21,22}$ In Phase III clinical trials, treatment with ledipasvir/sofosbuvir resulted in SVR12 rates of 94\%-99\%. ${ }^{23}$ Clinical trials with the four-drug combination (ombitasvir/ paritaprevir/ritonavir/dasabuvir) have resulted in SVR12 rates of $90 \%-100 \% .{ }^{24}$ In the near future, new, pangenotypic combinations of DAAs are expected to become available, appropriate for all fibrosis stages, with shorter durations of treatment and SVR rates approaching $100 \%$.

In summary, the new DAA-containing regimens are associated with improved SVR rates but bring differing regimen complexities and new spectra of potential side effects and antiviral resistance. These new regimens have been tested in controlled trials, where patients tend to have relatively more favorable outcomes. ${ }^{25}$ The effectiveness of these regimens in clinical practice must be determined. Outcomes research studies have shown that patient outcomes are affected by multiple factors, including the health care processes that are recommended in guidelines for the management of $\mathrm{HCV}$ infection. Here, we provide a review and analysis of studies of the management of HCV infection in real-world settings. We also summarize the processes-of-care measures recommended in guidelines for the management of $\mathrm{HCV}$ infection.

\section{Literature search}

A search of PubMed was conducted for primary studies of the management of HCV infection using the algorithm: "antiviral agents/therapeutic use"[Mesh Terms] AND "hepatitis c, chronic"[MeSH Terms] AND ("process assessment (health care)"[Mesh terms] OR "preventive health services"[Mesh terms] OR "quality of health care"[Mesh terms] OR "physician's practice patterns" [Mesh terms] OR "quality indicators, health care"[MeSH Terms]) AND (hasabstract[text] AND “2009/12/14”[PDat] : “2014/12/12”[PDat]) NOT review[publication type] NOT "clinical trial"[publication type] NOT "United States"[MeSH terms] NOT polymorphism*[title word] AND English[language] AND has abstract[text]. Bibliographies of articles identified in the search were screened.

\section{Conceptual framework}

An outcomes research study typically rests on a hypothesis relating an outcome, eg, a patient free of $\mathrm{HCV}$ infection, and a variable or set of variables upon which the outcome is hypothesized to be dependent, eg, antiviral drug treatment. The variables are categorized as either 1) an outcome or dependent variable or 2) an independent or predictor variable, upon which the outcome variable is dependent. Hence, the framework consists of sets of variables and the relationships between them (ie, their designation as outcome or predictor variables). The conceptual framework is shown as a graphical model in Figure 1. It has four domains, ie, categories of variables: 1 ) health care system structure, 2) patient characteristics, 3) process-of-care, and 4) patient outcomes.

Health care system structure refers to how health care is delivered to the patient and includes clinic and provider characteristics as well as the HCV surveillance system. ${ }^{26}$ Surveillance is defined as the "ongoing systematic collection, collation, analysis, interpretation of data; and the 


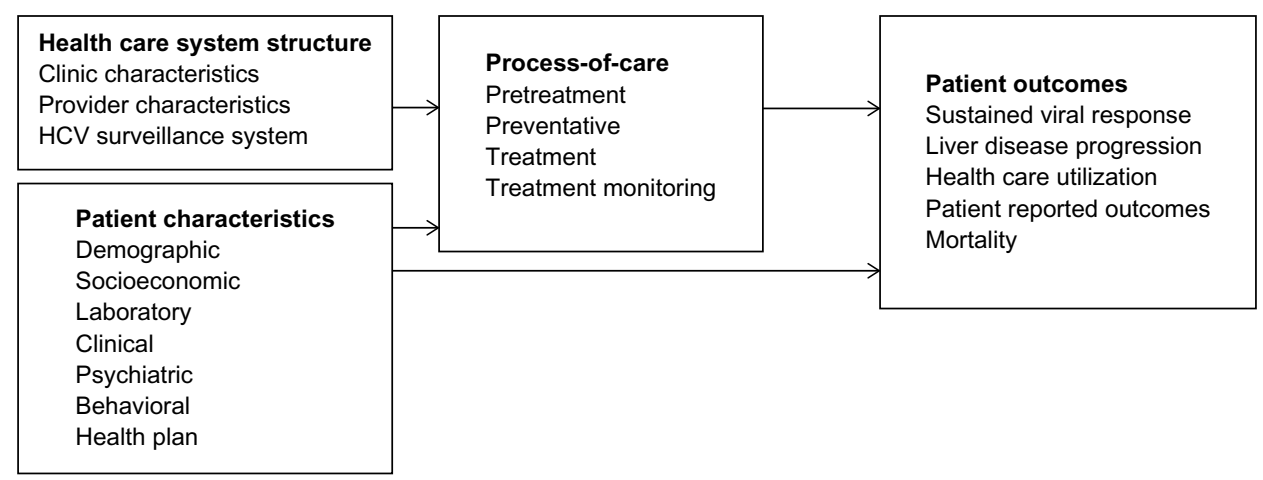

Figure I Graphical model of variable relationships in outcomes research studies of management of HCV infection.

Notes: Arrows run left to right from predictor variables to outcome variables. Process-of-care variables may be both predictor and outcome variables. The process-of-care variables are derived from Kanwal et al..$^{51}$

Abbreviation: $\mathrm{HCV}$, hepatitis $\mathrm{C}$ virus.

dissemination of information to those who need to know in order that action be taken". ${ }^{27,28}$ Process-of-care defines what is being delivered and includes four categories of care: pretreatment, preventative, treatment, and treatment monitoring. Patient characteristics are categorized as demographic, socioeconomic, laboratory, clinical (medical and psychiatric), behavioral, and health plan (health care insurance).

In this framework, the category "patient outcomes" is the ultimate outcome or dependent variable. The other variable categories are directly or indirectly predictors of this outcome variable. Health care system structures and patient characteristics are predictors of the process-of-care, which is a predictor of patient outcomes. Patient characteristics are also direct predictors of patient outcomes. The process-ofcare is the most immediate determinant of the effectiveness of management of HCV infection in patients. The optimum process-of-care is set out in clinical practice guidelines from professional societies. Some measures recommended in guidelines are also used as performance measures, also referred to as "quality-of-care measures", which are specific metrics used to monitor the delivery of health care. These guidelines are reviewed below.

\section{HCV management guidelines}

\section{Guidelines for the management of HCV infection}

Clinical practice guidelines (see list in Table S1), define the best-evidence practices and standards for the prevention and treatment of $\mathrm{HCV}$ infection, ie, they relate to the processof-care.

The populations targeted in guidelines vary. The United States Institute of Medicine's guideline for the prevention of hepatitis and liver cancer targets the general population. ${ }^{29}$ Three other US guidelines specifically refer to individuals born between 1945 and 1965 (a population at increased risk of $\mathrm{HCV}$ infection) ${ }^{30-33}$ Other guidelines focus on persons with chronic HCV infection, with an HIV coinfection, or patients with liver cancer (Table S1).

These HCV guidelines provide recommendations in the process-of-care categories of pretreatment (surveillance and testing for viral load and genotype), preventative (education, ie, knowledge and awareness of HCV prevention and HBV and hepatitis A virus [HAV] immunization), treatment (antiviral drug and treatment regimen), and treatment monitoring.

\section{Process-of-care measures recommended in guidelines} The specific process-of-care measures recommended in selected US and global guidelines are given in Table S2. The most extensive list is from the American Association for the Study of Liver Diseases and associated bodies (AASLD, IDSA, and IAS-USA). ${ }^{32}$ This guideline includes 22 measures in the four categories of care: 1) pretreatment, 2) preventative, 3) treatment, and 4) treatment monitoring and is the only guideline in Table S2 to include measures in the treatment monitoring category. The Centers for Disease Control and Prevention (CDC) and US Preventive Services Task Force (USPSTF) guidelines, both of which focus on persons born between 1945 and 1965, each contain only four measures: pretreatment (risk factor assessment, anti-HCV antibody test, and $\mathrm{HCV}$ diagnostic test in the USPSTF guideline), preventative (counseling about alcohol use in the $\mathrm{CDC}$ guideline), and treatment (antiviral treatment). ${ }^{30,31}$ Thus, only two measures are recommended in all four of the guidelines in Table S2: anti-HCV antibody test and antiviral treatment.

The 2015 guideline from the European Association for the Study of the Liver covers most of the items in the AASLD, IDSA, and IAS-USA guidelines, including specific recommendations regarding antiviral drug treatment and 
treatment monitoring. ${ }^{9}$ Specific drug regimens, including interferon-free regimens, are recommended, taking into account HCV genotype, degree of liver disease progression, potential drug-drug interactions, etc. Dose modification is discussed, and patient counseling regarding the importance of medication adherence is recommended. ${ }^{9}$ The World Health Organization's (WHO) guideline includes only five measures in the pretreatment, preventative, and treatment categories. $^{4}$

\section{Process-of-care measures as performance measures} Performance measures, also referred to as "quality-of-care" measures, are specific metrics used to assess the quality of medical care provided to patients with HCV infection. Specific process-of-care measures are used as performance measures in the United States. The specific process-of-care measures proposed by various US governmental and professional entities are listed in Table S3.

The American Medical Association-Physician Consortium for Performance Improvement (AMA-PCPI) work group created a list of 12 performance measures that focus on pretreatment, preventative, treatment, treatment monitoring, and patient outcomes (specifically SVR) to improve outcomes for adult patients with HCV (Table S3). ${ }^{34}$ The AMA-PCPI is the only organization listed in Table S3 to include patient outcomes in their list of performance measures. The Centers for Medicare and Medicaid Services'2014 Physician Quality Reporting System includes five HCV-specific quality indicators: pretreatment (confirmation of hepatitis $\mathrm{C}$ viremia and HCV genotyping), preventative (HAV vaccination/ immunity and HCV RNA test at treatment week 0), and treatment monitoring (HCV RNA testing between weeks 4 and 12 after initiation of treatment). ${ }^{35}$ Finally, the American Gastroenterological Association Institute's measures were adapted from an earlier set of measures from the Centers for Medicare and Medicaid Services. ${ }^{33}$

Three performance measures from the pretreatment and preventative categories were recommended in all of these four documents: 1) HCV genotyping, 2) HAV vaccination/ immunity, and 3) HCV RNA testing prior to commencing treatment.

\section{Outcomes research studies of $\mathrm{HCV}$ infection}

The search of PubMed with key terms for hepatitis C, antiviral agents, and health care process identified 27 unique reports of $\mathrm{HCV}$-specific outcomes research studies conducted in Europe, the United States, and elsewhere. These studies analyzed multiple variables within the domains of health care system structure, patient characteristics, and processof-care.

\section{Outcome (dependent) variables}

In studies conducted in countries outside the United States, initiation of antiviral treatment and treatment monitoring were the only process-of-care outcome variables, and SVR was the only patient outcome variable measured (Table 1). No pretreatment or preventative outcome variables were measured in these studies.

The data source in the majority of US studies was the Veterans Health Administration. Two US studies used health insurance claims data, ${ }^{36,37}$ one used data from several HIV clinics, ${ }^{38}$ and two were epidemiologic studies (Table 2). ${ }^{39,40}$ Antiviral treatment and SVR were the two outcome variables measured most frequently (Table 2). All of the other outcome variables in these US studies fell into the process-of-care category. Among other treatment outcome variables measured were type of antiviral treatment (by genotype), antiviral treatment completion, and whether antiviral treatment was offered. Other dependent variables were in the categories of pretreatment (referral to a specialty clinic, specialist evaluation, etc), preventative (HIV test, HAV serology test, HAV vaccination, etc), and treatment monitoring ( $\mathrm{HCV}$ test at treatment weeks 0,12 , etc). Kanwal et $\mathrm{al}^{41}$ used a composite outcome variable - whether the patient received $50 \%$ or more of a list of 23 process-of-care measures: seven each in the categories of pretreatment, preventative, and treatment monitoring, and two treatment measures.

\section{Predictor variables}

Variables predictive of dependent process-of-care and patient outcome variables are presented in Table 3. A “+” in Table 3 indicates that a statistically significant association was observed (either positive or negative) and a " 0 " indicates that no statistically significant association was found. The number of "+" or " 0 " signs for each association indicates the number of studies in which the association was reported.

The studies listed in Table 3 showed that the patient outcome, SVR, (see next-to-last column in Table 3 ) is affected by some process-of-care measures (optimum preventative care, treatment experience, treatment dose, treatment modification, treatment completion, and combination therapies) and by various patient characteristics - demographic (primarily age), laboratory (primarily HCV genotype), clinical/medical (primarily cirrhosis), clinical/psychiatric (depression), and behavioral (patient adherence and visit frequency). 


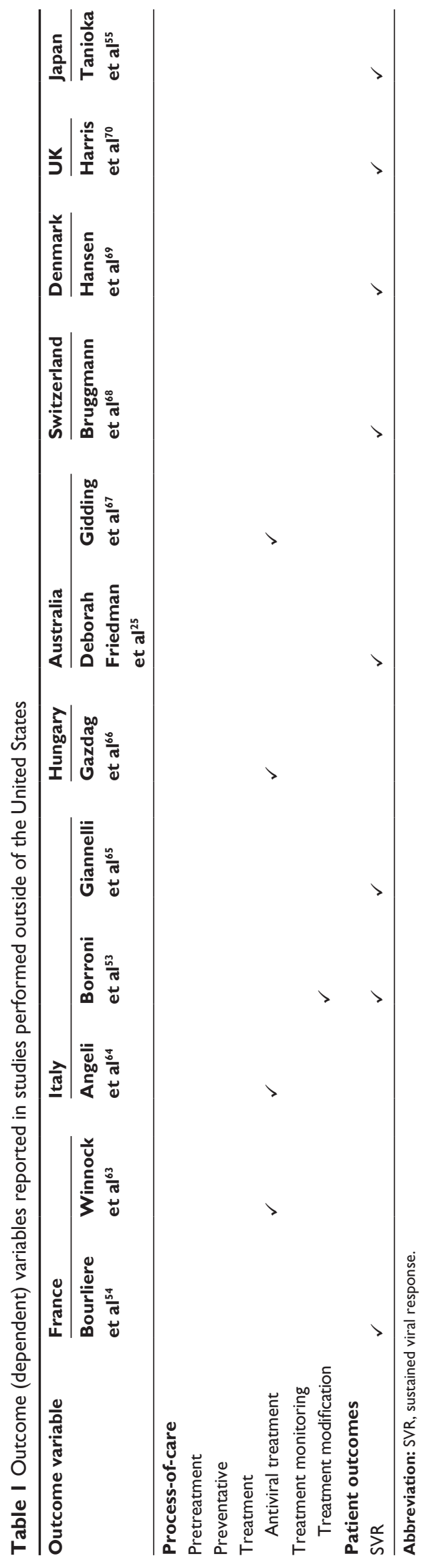

Antiviral treatment, the most frequently measured process-of-care outcome variable, is predicted by health care system structure variables, process-of-care variables, and by patient characteristics. The health care system structure variables influencing antiviral treatment were clinic characteristics (treatment facility) and provider characteristics (weekly patient $\mathrm{N}$, years at HIV clinic, and experience). The process-of-care measures were optimum pretreatment care and optimum preventative care. The patient characteristics were demographic (primarily age and race), laboratory (alanine aminotransferase level, hemoglobin, CD4 count, and genotype), clinical/medical (coronary artery disease/ cardiovascular disease, cirrhosis, and pulmonary disease), clinical/psychiatric (bipolar disorder and depression), and behavioral (primarily alcohol or illicit drug use) variables (Table 3).

\section{Discussion}

Outcomes research studies have analyzed dozens of variables in multiple categories within the domains of health care system structure, patient characteristics, and process-of-care (Table 3). The results of these studies indicated that some patient characteristics, eg, demographic (race) and behavioral (illicit drug use), were predictive of the process-of-care variable, antiviral treatment. Other patient characteristics, eg, demographic (age) and laboratory (HCV genotype), were predictive both of receiving antiviral treatment and of SVR (a patient outcome). In addition, some health care system structure variables were predictive of receiving antiviral treatment, and optimum preventative care (a process-of-care variable) was predictive of SVR.

The majority of the published outcomes research studies were conducted in the era of pegylated interferon/ribavirin as the standard for antiviral treatment, and so there are few published observational studies of the new DAAs and new DAA combinations. HCV-TARGET is an international consortium of HCV investigators who have established a common research database and are conducting a longitudinal observational study of the treatment of HCV therapy with DAAs. ${ }^{40}$ PITER is an ongoing longitudinal study of the impact of DAAs on the natural course of infection and long-term clinical outcomes. ${ }^{42}$ Clinical trials of multiple interferon-free combinations of DAAs have been completed or are ongoing. ${ }^{43-45}$ Outcomes research studies will be needed to clarify for which patient groups, and in which clinical settings, these new regimens are most effective. In the United States, the patient's health plan type may influence whether they receive the new DAAs. Most Medicaid plans currently limit access to sofosbuvir in 


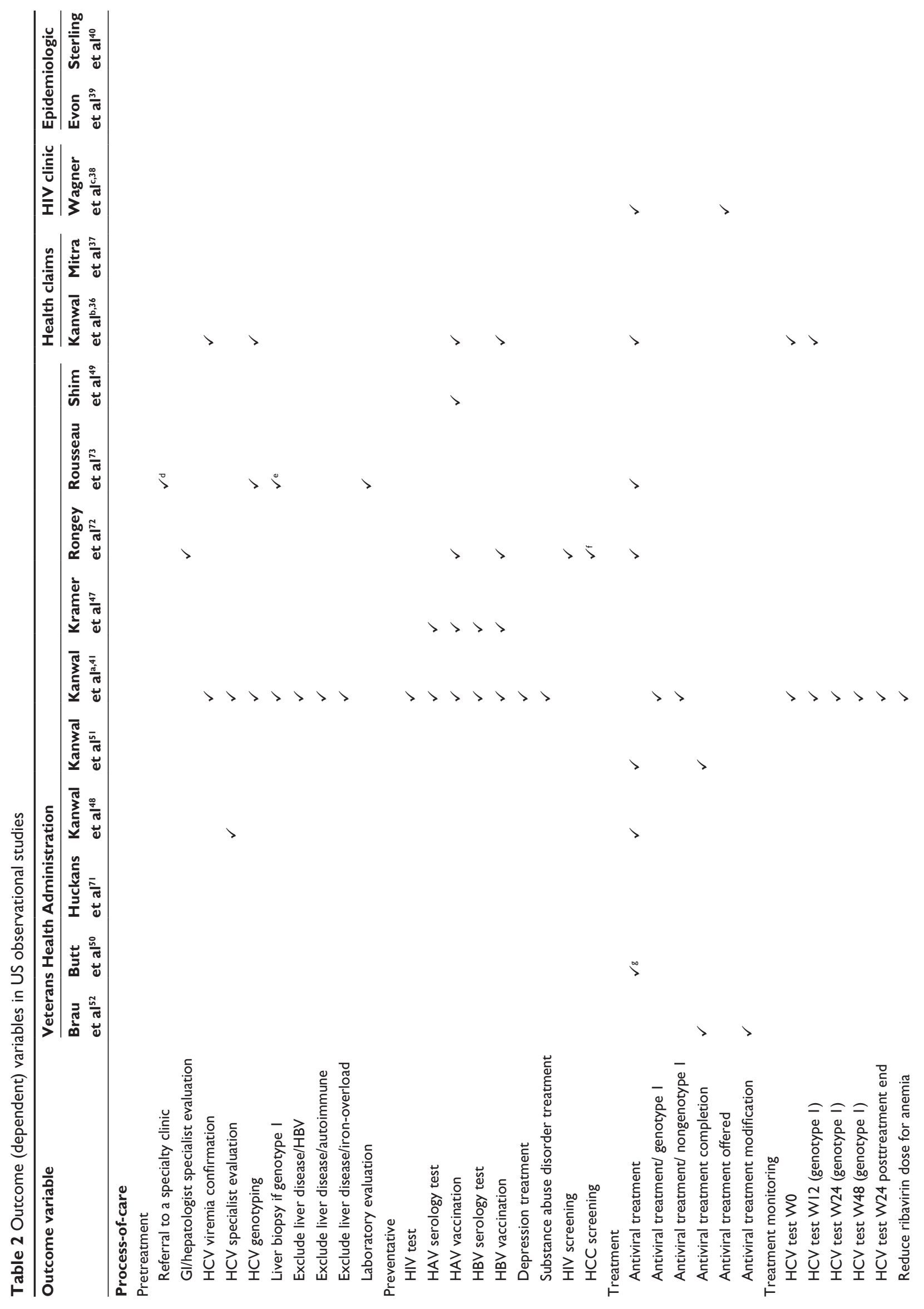




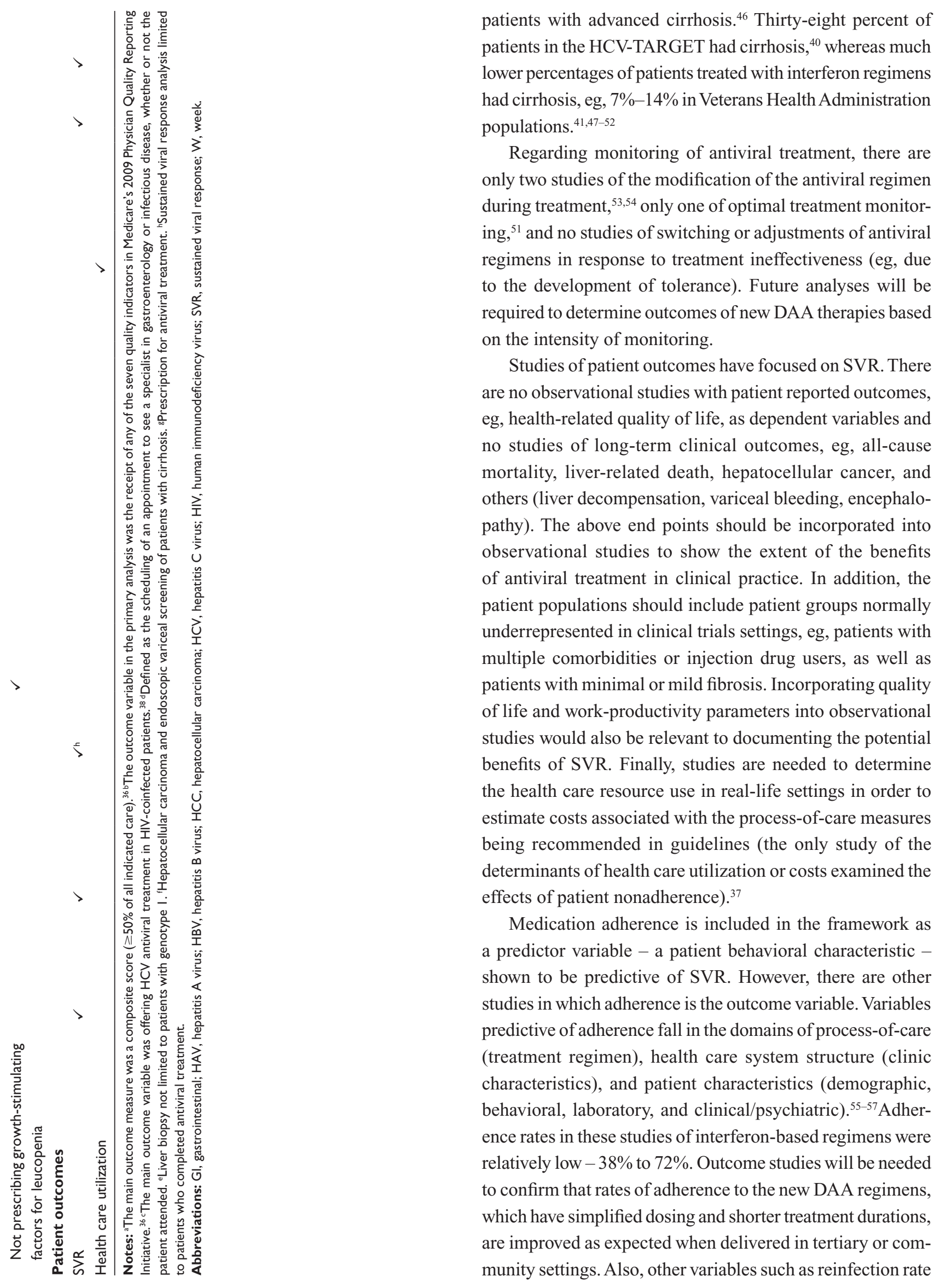

Infection and Drug Resistance 2016:9

submit your manuscript | www.dovepress.com 


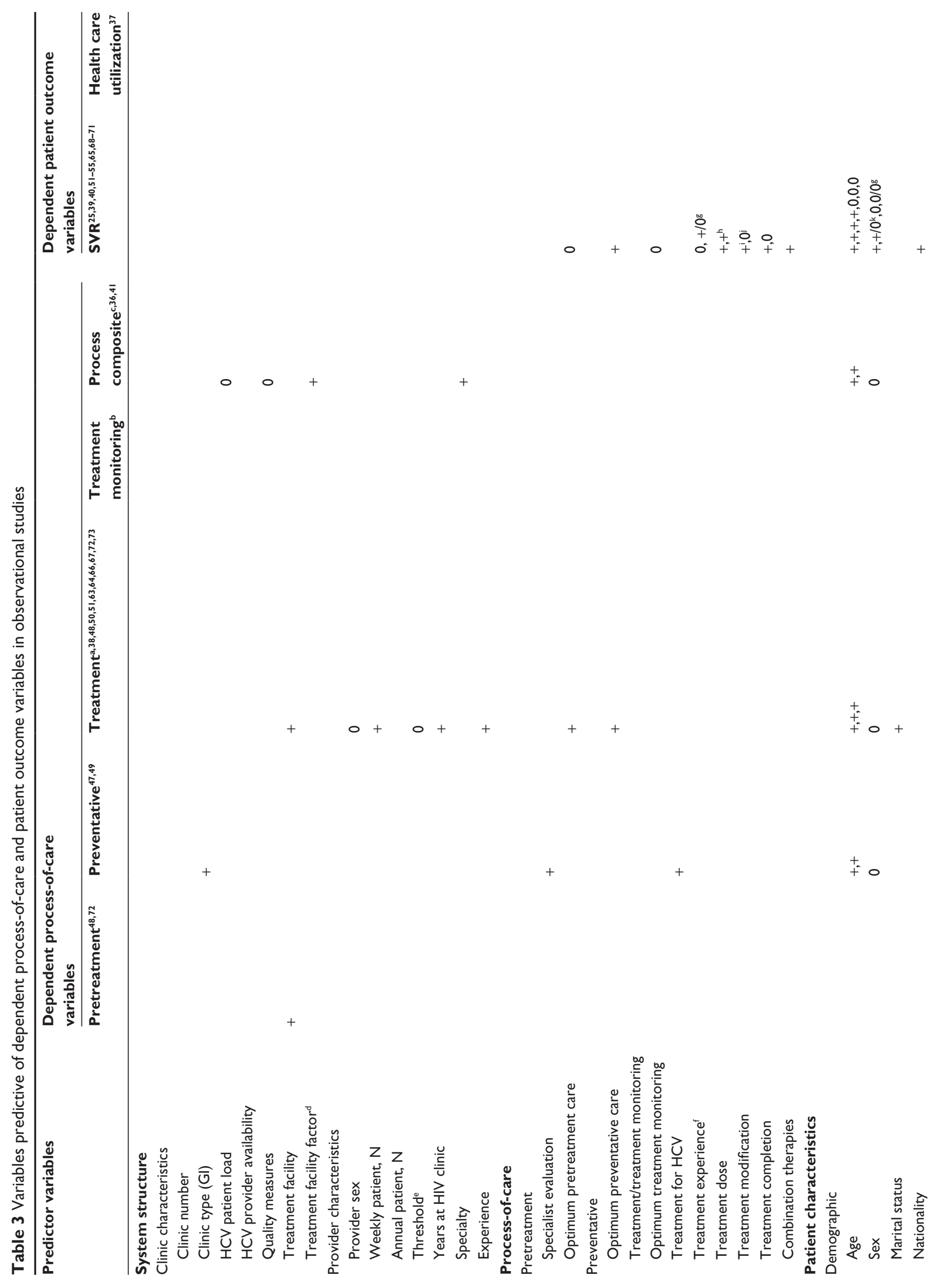




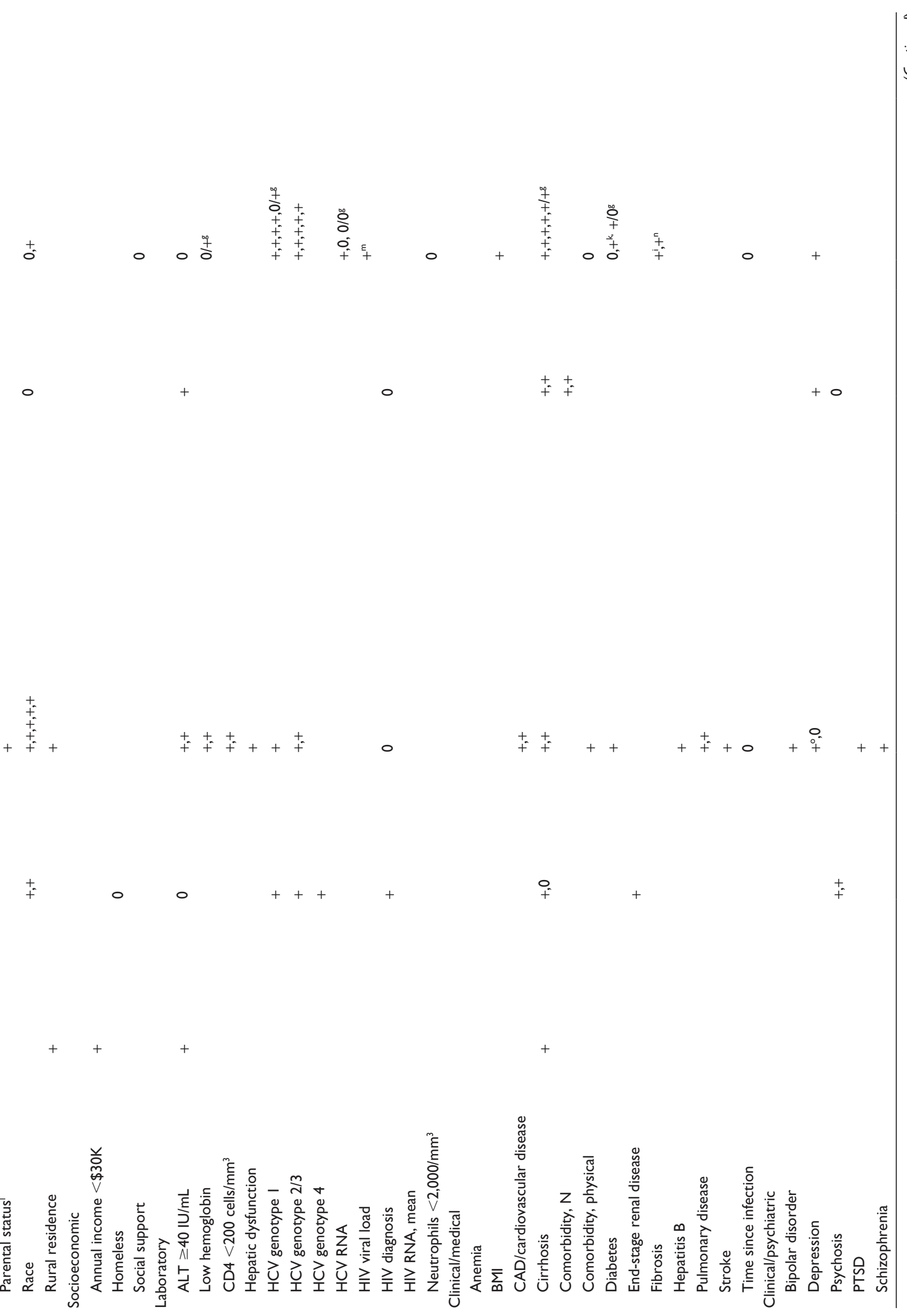




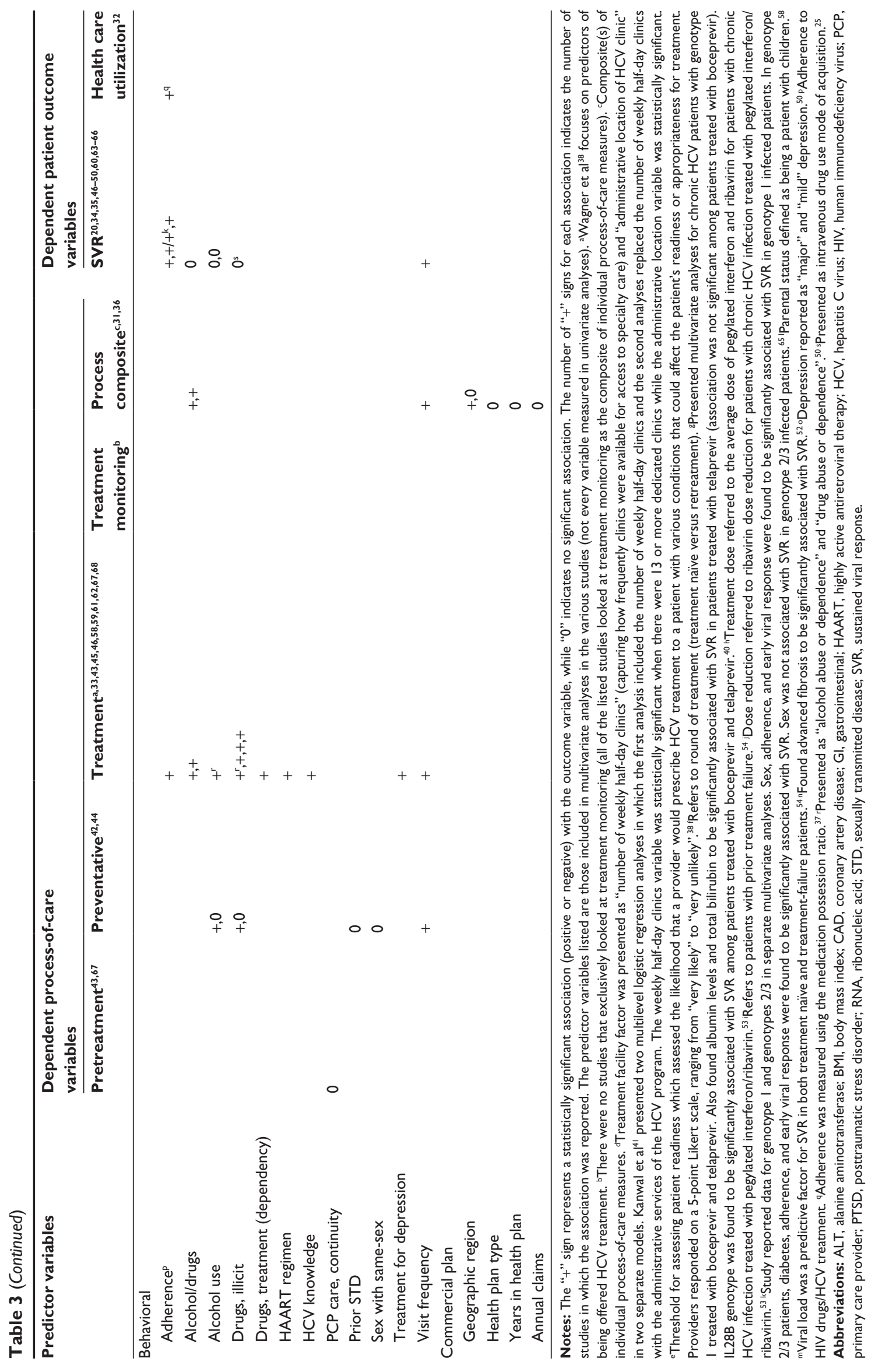


in high risk groups, eg, persons with injecting drug use, and the effect on prevalence and incidence in these groups will need to be captured in the future. Likewise, the dependency of SVR on baseline resistance associated variants may become important in some subgroups, and the prevalence of these variants after treatment failure will require scrutiny.

Because the conceptual framework applies to outcomes research studies, it does not include societal policy, whether specific to hepatitis or blood borne viral infection or targeted more generally to population health. ${ }^{58-60}$ Neither does the framework incorporate concepts such as education, social position, cultural, and societal norms, which are included in the CDC/WHO conceptual model of the social determinants of health, in which many of the relationships between parameters are cyclic. ${ }^{61} \mathrm{~A}$ framework with cyclic and bidirectional relationships is described by Rongey et al, ${ }^{62}$ who present a conceptual model to identify variables important in implementing a program of health care for chronically $\mathrm{HCV}$-infected US veterans. In contrast, the relationships between the four variable categories in Figure 1 are directed and acyclic, reflecting the analytical approach in outcomes research studies.

\section{Conclusion}

This analytical review shows that multiple variables in the domains of health care system structure, patient characteristics, and process-of-care affect SVR, virtually the only patient outcome variable studied to date. Future studies should address which among these factors influence treatment with the new antiviral drugs, the optimum antiviral drug regimens for individual patients, the effectiveness and health care costs of recommended process-of-care measures, and overall patient outcomes in clinical practice.

\section{Acknowledgment}

This study was funded by Janssen Global Services. ScribCo received funding from Janssen Global Services.

\section{Disclosure}

The coauthors report the following conflicts of interest: Urbano Sbarigia, Tom Denee, and Norris Turner are employees of Janssen Pharmaceutica. At the time of the development of this article, George J Wan was an employee of Janssen Global Services. Gary Rice has participated in advisory boards for AbbVie, Biogen Idec, Novartis, Janssen Global Services, and Pfizer Inc., has served as a consultant for Gilead, and is a member of speakers' bureaus for Novartis. Gary Rice received financial remuneration from Janssen
Global Services for his participation in the study. Geoffrey Dusheiko is a consultant for Janssen Global Services and received financial remuneration from Janssen Global Services for his participation in the study.

The authors report no other conflicts of interest in this work.

\section{References}

1. Lavanchy D. Evolving epidemiology of hepatitis C virus. Clin Microbiol Infect. 2011;17(2):107-115.

2. Mohd Hanafiah K, Groeger J, Flaxman AD, Wiersma ST. Global epidemiology of hepatitis $\mathrm{C}$ virus infection: new estimates of age-specific antibody to HCV seroprevalence. Hepatology. 2013;57(4):1333-1342.

3. Lavanchy D. The global burden of hepatitis C. Liver Int. 2009; 29(Suppl 1):74-81.

4. WHO Guidelines Approved by the Guidelines Review Committee. Guidelines for the Screening, Care and Treatment of Persons with Hepatitis C Infection. Geneva, Switzerland: World Health Organization; 2014.

5. Lehmann M, Meyer MF, Monazahian M, Tillmann HL, Manns MP, Wedemeyer $\mathrm{H}$. High rate of spontaneous clearance of acute hepatitis C virus genotype 3 infection. J Med Virol. 2004;73(3):387-391.

6. Tong MJ, el-Farra NS, Reikes AR, Co RL. Clinical outcomes after transfusion-associated hepatitis C. $N$ Engl J Med. 1995;332(22): 1463-1466.

7. Louie KS, St Laurent S, Forssen UM, Mundy LM, Pimenta JM. The high comorbidity burden of the hepatitis $\mathrm{C}$ virus infected population in the United States. BMC Infect Dis. 2012;12:86.

8. Hepatitis C. World Health Organization [updated]. Available from: http:// www.who.int/csr/disease/hepatitis/whocdscsrlyo2003/en/. Accessed March 16, 2016.

9. European Association for the Study of the Liver. EASL recommendations on treatment of hepatitis C 2015. J Hepatol. 2015;63(1):199-236.

10. Smith-Palmer J, Cerri K, Valentine W. Achieving sustained virologic response in hepatitis $\mathrm{C}$ : a systematic review of the clinical, economic and quality of life benefits. BMC Infect Dis. 2015;15(1):19.

11. European Association for the Study of the Liver. EASL Recommendations on Treatment of Hepatitis C. Geneva, Switzerland: European Association for the Study of the Liver; 2014.

12. Bacon BR, Gordon SC, Lawitz E, et al. Boceprevir for previously treated chronic HCV genotype 1 infection. N Engl J Med. 2011; 364(13):1207-1217.

13. Jacobson IM, McHutchison JG, Dusheiko G, et al. Telaprevir for previously untreated chronic hepatitis $\mathrm{C}$ virus infection. $N$ Engl $J$ Med. 2011;364(25):2405-2416

14. Poordad F, McCone J Jr, Bacon BR, et al. Boceprevir for untreated chronic HCV genotype 1 infection. N Engl J Med. 2011;364(13):1195-1206.

15. Zeuzem S, Andreone P, Pol S, et al. Telaprevir for retreatment of HCV infection. N Engl J Med. 2011;364(25):2417-2428.

16. US Food and Drug Administration. Daklinza (daclatasvir) [prescribing information]. Silver Spring, MD: US Food and Drug Administration; 2015.

17. US Food and Drug Administration. Sovaldi (sofosbuvir) [prescribing information]; 2013. http://www.accessdata.fda.gov/drugsatfda_docs/ label/2013/204671s0001bl.pdf. Accessed June 5, 2015.

18. US Food and Drug Administration. Olysio (simeprevir) [Prescribing information]; 2013. http://www.accessdata.fda.gov/drugsatfda_docs/ label/2013/205123s001lbl.pdf. Accessed June 5, 2015.

19. US Food and Drug Administration. Daklinza (daclatasvir) [Prescribing information]. 2015. http://packageinserts.bms.com/pi/pi_daklinza.pdf. Accesssed April 13, 2016

20. Younossi Z, Henry L. Systematic review: patient-reported outcomes in chronic hepatitis $\mathrm{C}$ - the impact of liver disease and new treatment regimens. Aliment Pharmacol Ther. 2015;41(6):497-520. 
21. US Food and Drug Administration. Harvoni (ledipasvir and sofosbuvir) [Prescribing information]; 2014. http://www.accessdata.fda.gov/drugsatfda_docs/label/2011/021511s023lbl.pdf. Accessed June 5, 2015.

22. US Food and Drug Administration. Viekira Pak (ombitasvir, paritaprevir, and ritonavir tablets; dasabuvir tablets) [Prescribing information]; 2014. http://www.accessdata.fda.gov/drugsatfda_docs/label/2014/2066191bl. pdf. Accessed June 5, 2015.

23. Gritsenko D, Hughes G. Ledipasvir/Sofosbuvir (harvoni): improving options for hepatitis C virus infection. P T. 2015;40(4):256-276.

24. A 4-drug combination (Viekira Pak) for hepatitis C. JAMA. 2015; 313(18):1857-1858

25. Deborah Friedman N, Green JH, Weber HM, et al. Hepatitis C virus treatment in the "real-world": how well do "real" patients respond? J Clin Exp Hepatol. 2014;4(3):214-220.

26. European Centre for Disease Prevention and Control. Surveillance and Prevention of Hepatitis $B$ and $C$ in Europe. Stockholm, Sweden: European Centre for Disease Prevention and Control; 2010.

27. Ataei B, Tayeri K, Kassaian N, Farajzadegan Z, Babak A. Hepatitis B and $\mathrm{C}$ among patients infected with human immunodeficiency virus in Isfahan, Iran: seroprevalence and associated factors. Hepat Mon. 2010;10(3):188-192.

28. Sosin DM. Draft framework for evaluating syndromic surveillance systems. J Urban Health. 2003;80(2 Suppl 1):i8-i13.

29. Institute of Medicine Committee on the Prevention and Control of Viral Hepatitis Infection. Hepatitis and Liver Cancer: A National Strategy for Prevention and Control of Hepatitis $B$ and $C$. Washington, DC: National Academies Press; 2010.

30. Moyer VA. Screening for hepatitis $\mathrm{C}$ virus infection in adults: U.S. Preventive Services Task Force recommendation statement. Ann Intern Med. 2013;159(5):349-357.

31. Smith BD, Morgan RL, Beckett GA, et al. Recommendations for the identification of chronic hepatitis $\mathrm{C}$ virus infection among persons born during 1945-1965. MMWR Recomm Rep. 2012;61(Rr-4):1-32.

32. American Association for the Study of Liver Diseases, Infectious Diseases Society of America, International Antiviral Society-USA. Recommendations for Testing, Managing, and Treating Hepatitis C. Alexandria, VA: American Association for the Study of Liver Diseases; 2014.

33. American Gastroenterological Association. Hepatitis $\mathrm{C}$ measures [updated]. Available from: http://www.gastro.org/practice/digestivehealth-outcomes-registry/clinical-content/hepatitis-c-measures. Accessed March 18, 2016.

34. American Medical Association. American Association for the Study of Liver Diseases/American Gastroenterological Association Institutel American Medical Association-convened Physician Consortium for Performance Improvement: Hepatitis C Performance Measure Set. Chicago, IL: American Medical Association; 2013.

35. Centers for Medicare and Medicaid Services. 2014 Physician Quality Reporting System (PQRS) Measure Specifications Manual for Claims and Registry Reporting of Individual Measures. Baltimore, MD: Centers for Medicare \& Medicaid Services; 2013.

36. Kanwal F, Schnitzler MS, Bacon BR, Hoang T, Buchanan PM, Asch SM. Quality of care in patients with chronic hepatitis $\mathrm{C}$ virus infection: a cohort study. Ann Intern Med. 2010;153(4):231-239.

37. Mitra D, Davis KL, Beam C, Medjedovic J, Rustgi V. Treatment patterns and adherence among patients with chronic hepatitis $\mathrm{C}$ virus in a US managed care population. Value Health. 2010;13(4):479-486.

38. Wagner G, Osilla KC, Garnett J, et al. Provider and patient correlates of provider decisions to recommend HCV treatment to HIV co-infected patients. J Int Assoc Physicians AIDS Care (Chic). 2012;11(4):245-251.

39. Evon DM, Esserman DA, Ramcharran D, Bonner JE, Fried MW. Social support and clinical outcomes during antiviral therapy for chronic hepatitis C. J Psychosom Res. 2011;71(5):349-356.

40. Sterling RK, Kuo A, Rustgi VK, et al. Virological outcomes and treatment algorithms utilisation in observational study of patients with chronic hepatitis $\mathrm{C}$ treated with boceprevir or telaprevir. Aliment Pharmacol Ther. 2015;41(7):671-685.
41. Kanwal F, Hoang T, Chrusciel T, et al. Association between facility characteristics and the process of care delivered to patients with hepatitis C virus infection. Dig Dis Sci. 2014;59(2):273-281.

42. Kondili LA, Vella S. PITER: an ongoing nationwide study on the real-life impact of direct acting antiviral based treatment for chronic hepatitis C in Italy. Dig Liver Dis. 2015;47(9):741-743.

43. Muir AJ, Poordad F, Lalezari J, et al. Daclatasvir in combination with asunaprevir and beclabuvir for hepatitis $\mathrm{C}$ virus genotype 1 infection with compensated cirrhosis. JAMA. 2015;313(17):1736-1744.

44. Poordad F, Sievert W, Mollison L, et al. Fixed-dose combination therapy with daclatasvir, asunaprevir, and beclabuvir for noncirrhotic patients with HCV genotype 1 infection. JAMA. 2015;313(17):1728-1735.

45. Lawitz E, Sulkowski MS, Ghalib R, et al. Simeprevir plus sofosbuvir, with or without ribavirin, to treat chronic infection with hepatitis $\mathrm{C}$ virus genotype 1 in non-responders to pegylated interferon and ribavirin and treatment-naive patients: the COSMOS randomised study. Lancet. 2014;384(9956):1756-1765.

46. Barua S, Greenwald R, Grebely J, Dore GJ, Swan T, Taylor LE. Restrictions for medicaid reimbursement of sofosbuvir for the treatment of hepatitis $\mathrm{C}$ virus infection in the United States. Ann Intern Med. 2015;163(3):215-223.

47. Kramer JR, Hachem CY, Kanwal F, Mei M, El-Serag HB. Meeting vaccination quality measures for hepatitis $\mathrm{A}$ and $\mathrm{B}$ virus in patients with chronic hepatitis C infection. Hepatology. 2011;53(1):42-52.

48. Kanwal F, Hoang T, Spiegel BM, et al. Predictors of treatment in patients with chronic hepatitis $\mathrm{C}$ infection - role of patient versus nonpatient factors. Hepatology. 2007;46(6):1741-1749.

49. Shim M, Khaykis I, Park J, Bini EJ. Susceptibility to hepatitis A in patients with chronic liver disease due to hepatitis $\mathrm{C}$ virus infection: missed opportunities for vaccination. Hepatology. 2005;42(3):688-695.

50. Butt AA, Justice AC, Skanderson M, Rigsby MO, Good CB, Kwoh CK. Rate and predictors of treatment prescription for hepatitis C. Gut. 2007;56(3):385-389.

51. Kanwal F, Hoang T, Chrusciel T, et al. Process of care for hepatitis C infection is linked to treatment outcome and virologic response. Clin Gastroenterol Hepatol. 2012;10(11):1270-1277.e3.

52. Brau N, Bini EJ, Currie S, et al. Black patients with chronic hepatitis C have a lower sustained viral response rate than non-Blacks with genotype 1 , but the same with genotypes $2 / 3$, and this is not explained by more frequent dose reductions of interferon and ribavirin*. J Viral Hepat. 2006;13(4):242-249.

53. Borroni G, Andreoletti M, Casiraghi MA, et al. Effectiveness of pegylated interferon/ribavirin combination in "real world" patients with chronic hepatitis C virus infection. Aliment Pharmacol Ther. 2008;27(9):790-797.

54. Bourliere M, Ouzan D, Rosenheim M, et al. Pegylated interferon- $\alpha 2 \mathrm{a}$ plus ribavirin for chronic hepatitis $\mathrm{C}$ in a real-life setting: the Hepatys French cohort (2003-2007). Antivir Ther. 2012;17(1):101-110.

55. Tanioka D, Iwasaki Y, Araki Y, et al. Factors associated with adherence to combination therapy of interferon and ribavirin for patients with chronic hepatitis C: importance of patient's motivation and physician's treatment experience. Liver Int. 2009;29(5):721-729.

56. Marcellin P, Chousterman M, Fontanges T, et al. Adherence to treatment and quality of life during hepatitis $\mathrm{C}$ therapy: a prospective, real-life, observational study. Liver Int. 2011;31(4):516-524.

57. Wagner G, Chan Osilla K, Garnett J, et al. Patient characteristics associated with HCV treatment adherence, treatment completion, and sustained virologic response in HIV coinfected patients. AIDS Res Treat. 2011;2011:903480.

58. World Health Organization. Prevention and Control of Viral Hepatitis Infection: Framework for Global Action. Geneva, Switzerland: WHO; 2012.

59. The Scottish Government. The Sexual Health and Blood Borne Virus Framework 2011-2015. Edinburgh, Scotland: The Scottish Government; 2011.

60. Department of Health. The NHS Outcomes Framework 2013-2014. London, UK: Department of Health; 2012. 
61. Centers for Disease Control and Prevention. The Social Determinants of Health. Atlanta, GA: Centers for Disease Control and Prevention; 2014 [updated March 21, 2014]. Available from: http://www.cdc.gov/ socialdeterminants/FAQ.html. Accessed February 3, 2015.

62. Rongey C, Asch S, Knight SJ. Access to care for vulnerable veterans with hepatitis $\mathrm{C}$ : a hybrid conceptual framework and a case study to guide translation. Transl Behav Med. 2011;1(4):644-651.

63. Winnock M, Bani-Sadr F, Pambrun E, et al. Factors associated with guideline-based hepatitis $\mathrm{C}$ virus (HCV) treatment initiation in HIV/ HCV-coinfected patients: role of comorbidities and physicians' perceptions. HIV Med. 2013;14(7):430-436.

64. Angeli E, Mainini A, Meraviglia P, et al. Eligibility and feasibility of the treatment of chronic hepatitis $\mathrm{C}$ in a cohort of Italian HIV-positive patients at a single HIV reference center. AIDS Patient Care STDS. 2011;25(5):295-301

65. Giannelli V, Giusto M, Farcomeni A, et al. Treatment of hepatitis C recurrence is less successful in female than in male liver transplant recipients. Transpl Int. 2012;25(4):448-454.

66. Gazdag G, Horvath G, Szabo O, Ungvari GS. Barriers to antiviral treatment in hepatitis $\mathrm{C}$ infected intravenous drug users. Neuropsychopharmacol Hung. 2010;12(4):459-462.

67. Gidding HF, Law MG, Amin J, et al. Predictors of deferral of treatment for hepatitis $\mathrm{C}$ infection in Australian clinics. Med J Aust. 2011;194(8):398-402.
68. Bruggmann P, Dampz M, Gerlach T, Kravecz L, Falcato L. Treatment outcome in relation to alcohol consumption during hepatitis $\mathrm{C}$ therapy: an analysis of the Swiss Hepatitis C Cohort Study. Drug Alcohol Depend. 2010;110(1-2):167-171.

69. Hansen N, Obel N, Christensen PB, et al. Effectiveness of treatment with pegylated interferon and ribavirin in an unselected population of patients with chronic hepatitis $\mathrm{C}$ : a Danish nationwide cohort study. BMC Infect Dis. 2011;11:177.

70. Harris HE, Costella A, Amirthalingam G, et al. Improved hepatitis C treatment response in younger patients: findings from the UK $\mathrm{HCV}$ National Register cohort study. Epidemiol Infect. 2012;140(10): 1830-1837.

71. Huckans M, Mitchell A, Ruimy S, Loftis J, Hauser P. Antiviral therapy completion and response rates among hepatitis $\mathrm{C}$ patients with and without schizophrenia. Schizophr Bull. 2010;36(1):165-172.

72. Rongey C, Shen H, Hamilton N, Backus LI, Asch SM, Knight S. Impact of rural residence and health system structure on quality of liver care. PLoS One. 2013;8(12):e84826.

73. Rousseau CM, Ioannou GN, Todd-Stenberg JA, et al. Racial differences in the evaluation and treatment of hepatitis $\mathrm{C}$ among veterans: a retrospective cohort study. Am J Public Health. 2008;98(5):846-852. 


\section{Supplementary materials}

Table SI Guidelines/recommendations for the management of HCV

\begin{tabular}{|c|c|c|c|c|}
\hline Agency $^{\mathrm{a}}$ & Year & Title & Subjects & Recommendation \\
\hline \multicolumn{5}{|l|}{ United States } \\
\hline $\begin{array}{l}\text { AASLD, IDSA, } \\
\text { IAS-USA' }^{\text {IASA }}\end{array}$ & 2014 & $\begin{array}{l}\text { Recommendations for testing, managing, } \\
\text { and treating hepatitis } C\end{array}$ & $\begin{array}{l}\text { Persons at increased risk of } \\
\text { HCV infection and adults } \\
\text { born between } 1945 \text { and } 1965\end{array}$ & $\begin{array}{l}\text { Screening/testing, management, } \\
\text { treatment }\end{array}$ \\
\hline $\mathrm{CDC}^{2}$ & 2012 & $\begin{array}{l}\text { Recommendations for the identification } \\
\text { of chronic hepatitis C virus infection } \\
\text { among persons born during } 1945-1965\end{array}$ & $\begin{array}{l}\text { Persons born between } 1945 \\
\text { and } 1965\end{array}$ & $\begin{array}{l}\text { Testing, preventative measures } \\
\text { (alcohol screening and } \\
\text { intervention), treatment }^{\mathrm{b}}\end{array}$ \\
\hline $1 O M^{c, 3}$ & 2010 & $\begin{array}{l}\text { Hepatitis and liver cancer: a national } \\
\text { strategy for prevention and control of } \\
\text { hepatitis } B \text { and } C\end{array}$ & General population $^{d}$ & $\begin{array}{l}\text { Surveillance, education, } \\
\text { immunization }\end{array}$ \\
\hline USPSTF ${ }^{4}$ & 2013 & $\begin{array}{l}\text { Screening for hepatitis } C \text { virus infection } \\
\text { in adults: US Preventive Services Task } \\
\text { Force recommendation statement }\end{array}$ & $\begin{array}{l}\text { Persons at high risk of HCV } \\
\text { infection and adults born } \\
\text { between } 1945 \text { and } 1965\end{array}$ & $\begin{array}{l}\text { Risk assessment, screening, } \\
\text { treatment }\end{array}$ \\
\hline \multicolumn{5}{|l|}{ Canada } \\
\hline CASL $^{5}$ & 2015 & $\begin{array}{l}\text { An update on the management of } \\
\text { chronic hepatitis C: consensus guidelines } \\
\text { from the Canadian Association for the } \\
\text { Study of the Liver }\end{array}$ & $\begin{array}{l}\text { Persons with chronic HCV } \\
\text { infection }\end{array}$ & Assessment, treatment, monitoring \\
\hline $\mathrm{ClHR}^{6}$ & 2014 & $\begin{array}{l}\text { CIHR Canadian HIV Trials Network } \\
\text { Coinfection and Concurrent Diseases } \\
\text { Core: Updated Canadian guidelines for } \\
\text { the treatment of hepatitis C infection in } \\
\text { HIV-hepatitis C coinfected adults }\end{array}$ & $\begin{array}{l}\text { HIV-hepatitis } C \text { coinfected } \\
\text { adults }\end{array}$ & Treatment \\
\hline \multicolumn{5}{|l|}{ Europe } \\
\hline $\mathrm{EASL}^{7}$ & 2015 & $\begin{array}{l}\text { EASL recommendations on treatment of } \\
\text { hepatitis } C\end{array}$ & $\begin{array}{l}\text { Persons with acute and } \\
\text { chronic } \mathrm{HCV} \text { infections }\end{array}$ & Testing, treatment, monitoring \\
\hline $\mathrm{NICE}{ }^{f, 8}$ & - & - & - & - \\
\hline \multicolumn{5}{|l|}{ Asia Pacific } \\
\hline APASL 9 & 2012 & $\begin{array}{l}\text { APASL consensus statements and } \\
\text { management algorithms for hepatitis } C \\
\text { virus infection }\end{array}$ & General population ${ }^{d}$ & $\begin{array}{l}\text { Surveillance, preventative } \\
\text { measures, testing, treatment }\end{array}$ \\
\hline \multicolumn{5}{|l|}{ Latin America } \\
\hline LAASL $^{10}$ & 2014 & $\begin{array}{l}\text { Latin American Association for the } \\
\text { Study of the Liver (LAASL) Clinical } \\
\text { Practice guidelines: management of } \\
\text { hepatocellular carcinoma }\end{array}$ & Persons with liver cancer & $\begin{array}{l}\text { Prevention, immunization, } \\
\text { management, surveillance, } \\
\text { treatment }\end{array}$ \\
\hline \multicolumn{5}{|l|}{ Global } \\
\hline WGO'I & 2013 & $\begin{array}{l}\text { Diagnosis, management, and prevention } \\
\text { of hepatitis } C\end{array}$ & $\begin{array}{l}\text { Children and adults with, or } \\
\text { exposed to, } \mathrm{HCV} \text { infection }\end{array}$ & $\begin{array}{l}\text { Screening, testing, diagnosis, } \\
\text { referral, treatment, care, follow-up }\end{array}$ \\
\hline WHO'2 & 2014 & $\begin{array}{l}\text { Guidelines for the screening, care and } \\
\text { treatment of persons with hepatitis C } \\
\text { infection }\end{array}$ & Persons with HCV infection & Screening, testing, care, treatment \\
\hline
\end{tabular}

Notes: aGovernment agency, quasiautonomous nongovernmental organization, professional society, or other entity. ${ }^{\mathrm{b} R e f e r s ~ t o ~ t h e ~ A m e r i c a n ~ A s s o c i a t i o n ~ f o r ~ t h e ~ S t u d y ~ o f ~}$ Liver Diseases $201 \mathrm{I}$ guidelines for treatment recommendations. ${ }^{13}$ The $201 \mathrm{I}$ guidelines have since been updated and have been replaced by the 2014 guidelines. ${ }^{1} \mathrm{C}$ Guidelines are for Hepatitis B and C. ${ }^{d}$ General population and/or various or unspecified target populations. ${ }^{~}$ Screening tests include antibody testing followed by a confirmatory PCR. 'Guidelines by NICE have been paused. ${ }^{8}$

Abbreviations: AASLD, American Association for the Study of Liver Diseases; APASL, Asian Pacific Association for the Study of the Liver; CASL, Canadian Association for the Study of the Liver; CDC, Centers for Disease Control and Prevention; CIHR, Canadian Institutes of Health Research; EASL, European Association for the Study of the Liver; HCV, hepatitis C virus; HIV, human immunodeficiency virus; IAS-USA, International Antiviral Society-USA; IDSA, Infectious Diseases Society of America; IOM, Institute of Medicine; LAASL, Latin American Association for the study of the Liver; NICE, National Institute for Health and Care Excellence; PCR, polymerase chain reaction; USPSTF, US Preventive Services Task Force; WGO, World Gastroenterology Organization; WHO, World Health Organization. 
Table S2 Process-of-care measures in selected guidelines

\begin{tabular}{|c|c|c|c|c|}
\hline \multirow[t]{2}{*}{ Measure } & \multicolumn{4}{|l|}{ Guideline } \\
\hline & $\begin{array}{l}\text { AASLD, IDSA, } \\
\text { IAS-USA' }\end{array}$ & $\mathrm{CDC}^{2}$ & USPSTF $^{4}$ & WHO'2 \\
\hline \multicolumn{5}{|l|}{ Pretreatment } \\
\hline Evaluation by $\mathrm{HCV}$ practitioner ${ }^{\mathrm{a}}$ & $\checkmark$ & & & \\
\hline Risk factor assessment & $\checkmark$ & $\sqrt{b}$ & $\checkmark$ & \\
\hline Anti-HCV antibody test & $\checkmark$ & $\sqrt{b}$ & $\checkmark$ & $\mathfrak{V}^{\mathrm{c}}$ \\
\hline HCV RNA diagnostic test & $\checkmark$ & & $\checkmark$ & $\checkmark$ \\
\hline HCV genotyping & $\checkmark$ & & & \\
\hline Referral of decompensated cirrhosis patients & $\checkmark$ & & & \\
\hline \multicolumn{5}{|l|}{ Preventative } \\
\hline HAV vaccination/immunity & $\checkmark$ & & & \\
\hline HBV vaccination/immunity & $\checkmark$ & & & \\
\hline Evaluation for advanced hepatic fibrosis & $\checkmark$ & & & $\checkmark$ \\
\hline Counseling regarding preventing $\mathrm{HCV}$ transmission & $\checkmark$ & & & \\
\hline \multicolumn{5}{|l|}{ Counseling regarding contraception } \\
\hline Counseling regarding alcohol use & $\checkmark$ & $\checkmark$ & & $\checkmark$ \\
\hline Assessment for potential antiviral drug-drug interactions & $\checkmark$ & & & \\
\hline Laboratory tests at treatment $\mathrm{W}^{\mathrm{d}}$ & $\checkmark$ & & & \\
\hline HCV RNA test at treatment $W 0^{d}$ & $\checkmark$ & & & \\
\hline \multicolumn{5}{|l|}{ Treatment } \\
\hline Antiviral treatment & $\checkmark$ e & $\checkmark^{\mathrm{f}}$ & $\checkmark$ & $\checkmark$ \\
\hline \multicolumn{5}{|l|}{ Treatment monitoring } \\
\hline HCV RNA test at treatment WI2 & $\checkmark$ & & & \\
\hline HCV RNA test at treatment $\mathrm{W} 4, \mathrm{WI} 2$, and at treatment end & $\checkmark$ & & & \\
\hline Laboratory testing periodically during treatment & $\checkmark$ & & & \\
\hline Ongoing assessment liver disease ${ }^{g}$ & $\checkmark$ & & & \\
\hline Retreatment if prior antiviral therapy failed & $\checkmark$ & & & \\
\hline Liver disease progression assessment if antivirals failed & $\checkmark$ & & & \\
\hline Monitoring for pregnancy-related issues if ribavirin used & $\checkmark$ & & & \\
\hline
\end{tabular}

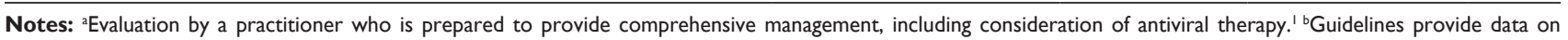
different testing methods ( $\mathrm{HCV}$ antibody testing, $\mathrm{HCV}$ RNA testing, $\mathrm{HCV}$ viral load testing, and liver enzyme tests). 'Guidelines recommend that HCV serology testing be offered to screen and identify persons with $\mathrm{HCV}$ infection and that nucleic acid testing for the detection of HCV RNA be performed directly following a positive HCV serological test to establish the diagnosis of chronic HCV. 'WO: treatment week 0 , ie, prior to commencement of antiviral treatment. Multiple treatment recommendations depending on patient category. 'Refers to the American Association for the Study of Liver Diseases 201 I guidelines for treatment recommendations. ${ }^{13}$ The 2011 guidelines have since been updated and have been replaced by the 2014 guidelines. Iln persons for whom antiviral treatment is deferred.

Abbreviations: AASLD, American Association for the Study of Liver Diseases; CDC, Centers for Disease Control and Prevention; HAV, hepatitis A virus; HBV, hepatitis B virus; HCV, hepatitis C virus; IAS-USA, International Antiviral Society-USA; IDSA, Infectious Diseases Society of America; RNA, ribonucleic acid; USPSTF, US Preventive Services Task Force; W, week; WHO, World Health Organization. 
Table S3 US performance measures

\begin{tabular}{|c|c|c|c|}
\hline Performance measure & AMA-PCPI ${ }^{14}$ & 2014 PQRS $^{15}$ & $\mathbf{A G A}^{16}$ \\
\hline \multicolumn{4}{|l|}{ Pretreatment } \\
\hline Confirmation of hepatitis $C$ viremia & $\checkmark$ & $\sqrt{ } a^{2}$ & \\
\hline HCV genotyping & $\checkmark$ & $\checkmark$ & $\checkmark$ \\
\hline \multicolumn{4}{|l|}{ Preventative } \\
\hline HAV vaccination/immunity & $\checkmark$ & $\checkmark$ & $\checkmark$ \\
\hline HBV vaccination/immunity & $\checkmark$ & & $\checkmark$ \\
\hline Counseling regarding contraception & & & $\checkmark$ \\
\hline Counseling regarding alcohol use & $\checkmark$ & & $\checkmark$ \\
\hline HCV RNA test at treatment W0 ${ }^{b}$ & $\checkmark$ & $\checkmark$ & $\checkmark$ \\
\hline One-time screening for $\mathrm{HCV}$ for patients at risk & $\sqrt{c}$ & & \\
\hline Annual HCV screening for patients who are active injection drug users & $\sqrt{c}$ & & \\
\hline Referral to treatment for patients identified with $\mathrm{HCV}$ infection & $\checkmark \mathrm{c}$ & & \\
\hline \multicolumn{4}{|l|}{ Treatment } \\
\hline Antiviral treatment & $\checkmark$ & & $\checkmark$ \\
\hline \multicolumn{4}{|l|}{ Treatment monitoring } \\
\hline HCV RNA test at treatment WI2 & & & $\checkmark$ \\
\hline HCV RNA testing between weeks 4 and 12 after initiation of treatment & $\checkmark$ & $\checkmark$ & \\
\hline Discontinuation of antiviral therapy for inadequate viral response & $\checkmark$ & & \\
\hline Discussion and shared decision making surrounding treatment options & $\checkmark$ & & \\
\hline \multicolumn{4}{|l|}{ Patient outcomes } \\
\hline SVR & $\checkmark$ & & \\
\hline
\end{tabular}

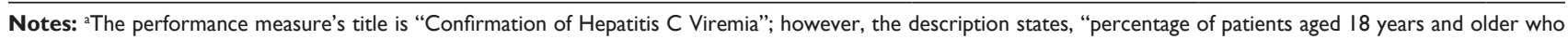
are hepatitis $C$ antibody positive seen for an initial evaluation for whom HCV RNA testing was ordered or previously performed". bW0: treatment week 0, ie, prior to commencement of antiviral treatment. 'Presented as one measure with three parts.

Abbreviations: AGA, American Gastroenterological Association; AMA, American Medical Association; HAV, hepatitis A virus; HBV, hepatitis B virus; HCV, hepatitis C virus; PCPI, Physician Consortium for Performance Improvement; PQRS, Physician Quality Reporting System; RNA, ribonucleic acid; SVR, sustained viral response; W, week.

\section{References}

1. American Association for the Study of Liver Diseases, Infectious Diseases Society of America, International Antiviral Society-USA. Recommendations for Testing, Managing, and Treating Hepatitis C. Alexandria, VA: American Association for the Study of Liver Diseases; 2014.

2. Smith BD, Morgan RL, Beckett GA, et al. Recommendations for the identification of chronic hepatitis $\mathrm{C}$ virus infection among persons born during 1945-1965. MMWR Recomm Rep. 2012;61(Rr-4):1-32.

3. Institute of Medicine Committee on the Prevention and Control of Viral Hepatitis Infection. Hepatitis and Liver Cancer: A National Strategy for Prevention and Control of Hepatitis $B$ and $C$. Washington, DC: National Academies Press; 2010.

4. Moyer VA. Screening for hepatitis $C$ virus infection in adults: U.S. Preventive Services Task Force recommendation statement. Ann Intern Med. 2013;159(5):349-357.

5. Myers RP, Shah H, Burak K, Cooper C, Feld J. An update on the management of chronic hepatitis C: 2015 consensus guidelines from the Canadian Association for the Study of the Liver. Can J Gastroenterol Hepatol. 2015;29(1):19-34.

6. Hull M, Shafran S, Tseng A, Giguere P, Klein MB, Cooper C. CIHR Canadian HIV Trials Network Co-Infection and Concurrent Diseases Core: Updated Canadian guidelines for the treatment of hepatitis C infection in HIV-hepatitis C coinfected adults. Can J Infect Dis Med Microbiol. 2014;25(6):311-320.

7. European Association for the Study of the Liver. EASL recommendations on treatment of hepatitis C 2015. J Hepatol. 2015;63(1):199-236.

8. National Institute for Health and Care Excellence. Hepatitis C [updated]. Available from: https://www.nice.org.uk/guidance/indevelopment/gidcgwave0666. Accessed March 18, 2016.

9. Omata M, Kanda T, Yu M, et al. APASL consensus statements and management algorithms for hepatitis $\mathrm{C}$ virus infection. Hepatol Int. 2012;2(6):400-435.
10. Mendez-Sanchez N, Ridruejo E, Alves de Mattos A, et al. Latin American Association for the Study of the Liver (LAASL) clinical practice guidelines: management of hepatocellular carcinoma. Ann Hepatol. 2014;13(Suppl 1):S4-S40.

11. World Gastroenterology Organisation. World Gastroenterology Organisation Global Guidelines: Diagnosis, Management, and Prevention of Hepatitis C. Milwaukee, WI: World Gastroenterology Organisation; 2013.

12. WHO Guidelines Approved by the Guidelines Review Committee. Guidelines for the Screening, Care and Treatment of Persons with Hepatitis C Infection. Geneva, Switzerland: World Health Organization; 2014.

13. Ghany MG, Nelson DR, Strader DB, Thomas DL, Seeff LB. An update on treatment of genotype 1 chronic hepatitis $\mathrm{C}$ virus infection: 2011 practice guideline by the American Association for the Study of Liver Diseases. Hepatology. 2011;54(4):1433-1444.

14. American Medical Association. American Association for the Study of Liver Diseases/American Gastroenterological Association Institutel American Medical Association-convened Physician Consortium for Performance Improvement: Hepatitis C Performance Measure Set. Chicago, IL: American Medical Association; 2013.

15. Centers for Medicare and Medicaid Services. 2014 Physician Quality Reporting System (PQRS) Measure Specifications Manual for Claims and Registry Reporting of Individual Measures. Baltimore, MD: Centers for Medicare \& Medicaid Services; 2013.

16. American Gastroenterological Association. Hepatitis C measures [updated]. Available from: http://www.gastro.org/practice/digestivehealth-outcomes-registry/clinical-content/hepatitis-c-measures. Accessed March 18, 2016. 
Infection and Drug Resistance

\section{Publish your work in this journal}

Infection and Drug Resistance is an international, peer-reviewed openaccess journal that focuses on the optimal treatment of infection (bacterial, fungal and viral) and the development and institution of preventive strategies to minimize the development and spread of resistance. The journal is specifically concerned with the epidemiology of antibiotic

resistance and the mechanisms of resistance development and diffusion in both hospitals and the community. The manuscript management system is completely online and includes a very quick and fair peerreview system, which is all easy to use. Visit http://www.dovepress.com/ testimonials.php to read real quotes from published authors.

Submit your manuscript here: http://www.dovepress.com/infection-and-drug-resistance-journal 